\title{
Speciation of Cr(III) and Cr(VI) in Environmental Water Determined by Selective Separation and Preconcentration on the PBST-RSP
}

\author{
Zhi-gang Yuan \\ School of Materials Science and Engineering, Shenyang \\ Ligong University, Shenyang, Liaoning, 110159, P. R. \\ China \\ Liaoning Shentong blower manufacturing Co., Ltd. Chang \\ tu, Liaoning, 112509, P. R. China \\ email:sylgdxyuan@163.com,
}

\begin{abstract}
In this paper, a new method for the speciation, separation and preconcentration of $\operatorname{Cr}(\mathrm{VI})$ and $\operatorname{Cr}$ (III) in water was developed. The procedure presented based on two forms of chromium show different adsorption capacities on the Porous nano-barium strontium titanate by reversed-phase suspension polymerization and sol-gel method (PBST-RSP) at different $\mathrm{pH}$ values, that is, $\mathrm{Cr}$ (VI) selectively retained at $\mathbf{p H}$ 1-2, but $\mathrm{Cr}$ (III) can't be adsorbed. Whereas Cr (III) retained at pH 7-14, but $\mathrm{Cr}(\mathrm{VI})$ can't be adsorbed. Hence complete separation of the $\operatorname{Cr}(\mathrm{VI})$ and $\operatorname{Cr}(\mathrm{III})$ is possible. Retained $\mathrm{Cr}(\mathrm{VI})$ and $\mathrm{Cr}(\mathrm{III})$ were eluted with $1 \mathrm{~mol} / \mathrm{L} \mathrm{HCl}$ and $1 \mathrm{~mol} / \mathrm{L}$ $\mathrm{NaOH}$, respectively. The $\mathrm{Cr}(\mathrm{VI})$ and $\mathrm{Cr}(\mathrm{III})$ concentration were measured by flame atomic absorption spectrometer. The method was successfully applied for the speciation of chromium in surface water and drinking water samples with successfully results.
\end{abstract}

Keywords-Porous nano-barium strontium titanate, Speciation analysis, Chromium, Water

\section{INTRODUCTION}

In the recently yeas, with the increase of human activities, mass of environmental pollutants are discharged into the environment, leading to serious environmental problems. Among all environmental pollutants, heavy metal ions are now catching much attention because of the remarkable toxicity. And speciation study of heavy metal ions is very important since toxicity of some of them depends on their chemical properties, oxidation states, and bioavailabilities [1]. Chromium is one of the most abundant elements having the potential to contaminate water, and so can be a major source of drinking water contamination. In water, chromium can usually be found in two different oxidation states including hydrated $\mathrm{Cr}(\mathrm{III})$ and $\mathrm{Cr}(\mathrm{VI})$ species with different physiological effects [2]. $\mathrm{Cr}$ (III) is a trace element essential for maintaining glucose, cholesterol, and fatty acid metabolisms in biological cells [3-5]. But $\mathrm{Cr}(\mathrm{VI})$ with a high oxidation potential and relatively small size can easily permeate through biological cell membranes, and is known as a carcinogenic and mutagenic substance for humans [3]. Due to the high solubility of $\mathrm{Cr}(\mathrm{VI})$ in water, drinking water could be one of the routes to the incorporation of chromium into the human body. The ministry of health of the people's republic of china and standardization administration of the people's republic of china has set a limit of $0.05 \mathrm{mg} / \mathrm{L}$ of chromium(VI) for drinking water[6].and The United States Environmental

\author{
Wei-nan $\mathrm{Wu}$ \\ Environmental Management of Solid Waste, Shenyang, \\ Liaoning, 110161, P. R. China \\ email:wuweinan88@sina.com
}

Protection Agency (EPA) has set a limit of $0.1 \mathrm{mg} / \mathrm{L}$ of total chromium for drinking water. The guideline value recommended by World Health Organization (WHO) is 50 $\mu \mathrm{g} / \mathrm{L}$ [7]. For this reason, determination of chromium in environmental samples as natural water, waste water samples and drinking water samples has become very important.

Owing to these, precise and accurate determination of both species in environmental samples is essential. The methods for determination and speciation of chromium(III) and chromium(VI) species mainly selective techniques are solid phase extraction followed by instrumental analysis $[5,8,9]$. But porous nano-barium strontium titanate by reversed-phase suspension polymerization and sol-gel method (PBST-RSP) sorbents has not studied. In this work, a new method using PBST-RSP as sorbent has been developed for the preconcentration and separation of $\mathrm{Cr}$ (III) and $\mathrm{Cr}$ (VI) in water.

\section{EXPERIMENTAL}

\section{A Apparatus and reagents}

A WYX-9003A atomic absorption spectrometer (Shenyang Yi Tong Analytical Instrument Co., Ltd.), equipped with hollow cathode lamps for chromium. The operating conditions were summarized in Table 1.

The $\mathrm{pH}$ values were measured with a PHS-3C acidometer (Shanghai REX Instrument Factory, Shanghai, China) supplied with a combined electrode.

TABLE 1. FAAS OPERATING CONDITIONS

\begin{tabular}{|c|c|c|c|c|c|c|}
\hline $\begin{array}{l}\text { Elem } \\
\text { ent }\end{array}$ & $\begin{array}{l}\text { Wave } \\
\text { length( } \\
\text { nm) }\end{array}$ & $\begin{array}{l}\text { Spect } \\
\text { ral } \\
\text { band } \\
\text { width } \\
(\mathrm{nm})\end{array}$ & $\begin{array}{c}\text { Lam } \\
\mathrm{p} \\
\text { curre } \\
\mathrm{nt} \\
(\mathrm{mA} \\
)\end{array}$ & $\begin{array}{l}\text { Burn } \\
\text { er } \\
\text { heig } \\
\text { ht } \\
\text { (mm } \\
\text { ) }\end{array}$ & $\begin{array}{l}\text { Acetylen } \\
\text { e gas } \\
\text { consump } \\
\text { tion } \\
(\mathrm{mL} / \mathrm{min} \\
)\end{array}$ & $\begin{array}{c}\text { Air } \\
\text { consump } \\
\text { tion } \\
(\mathrm{mL} / \mathrm{min} \\
)\end{array}$ \\
\hline $\mathrm{Cr}$ & 391.1 & 0.4 & 12 & 5.0 & 1250 & 5000 \\
\hline
\end{tabular}

The porous nano-barium strontium titanate by reversed-phase suspension polymerization and sol-gel method (PBST-RSP) was prepared by a citric acid complex sol-gel method in our laboratory as previously described elsewhere [10].

The reagents, $\mathrm{Cr}\left(\mathrm{NO}_{3}\right)_{3}, \mathrm{HCl}$ and $\mathrm{NaOH}$ was guarantee reagent, $\mathrm{K}_{2} \mathrm{Cr}_{2} \mathrm{O}_{7}$ was primary reagent. Stock standard 
solutions of $\mathrm{Cr}$ (III) and $\mathrm{Cr}$ (VI) were prepared by dissolving appropriate amount of $\mathrm{Cr}\left(\mathrm{NO}_{3}\right)_{3}$ in $0.5 \mathrm{~mol} / \mathrm{L} \mathrm{HCl}$ and $\mathrm{K}_{2} \mathrm{Cr}_{2} \mathrm{O}_{7}$ in distilled water. The water in this study was distilled water.

\section{$B$ General separation and preconcentration procedure}

A specific amount of $\mathrm{Cr}(\mathrm{III})$ and $\mathrm{Cr}(\mathrm{VI})$ solution was placed into a $50 \mathrm{~mL}$ calibrated mark erlenmeyer flask with plug. Solutions were adjusted to a $\mathrm{pH} 12-13$ in the case of preconcentration of $\mathrm{Cr}$ (III) in the mark erlenmeyer flask 1 and to $\mathrm{pH} 1$ in the case of preconcentration of $\mathrm{Cr}(\mathrm{VI})$ in the mark erlenmeyer flask 2. The preconcentration of investigated species was then performed simultaneously. $0.1 \mathrm{~g}$ of PBST-RSP was added. Covered with a plug, shaken for $10 \mathrm{~min}$ in a bath shaker (200r/min). Then the supernatant fluid was poured out. Sorbed $\mathrm{Cr}$ (III) and $\mathrm{Cr}$ (VI) ions were desorbed with $5 \mathrm{~mL}$ of $1 \mathrm{~mol} \cdot \mathrm{L}-1 \mathrm{HCl}$ and 1 mol.L-1 NaOH, respectively. Eluted samples were analyzed with atomic absorption spectrometry, the absorption and preconcentration capacity was calculated.

\section{Influence of pH on adsorption of Cr (III) and Cr (VI)}

Differences between sorption energies of $\mathrm{Cr}$ (III) and $\mathrm{Cr}$ (VI) on the PBST-RSP surface provide the main reason for their selective preconcentration on the surface. Results concerning the effect of $\mathrm{pH}$ on the adsorption are presented in Fig.1, and it is apparent that $\mathrm{pH}>7$ is appropriate for the preconcentration of $\mathrm{Cr}$ (III) on GBST. The quantitative recovery of $\mathrm{Cr}(\mathrm{VI})$ is obtained at $\mathrm{pH}$ values $\leq 2$. Depending on the $\mathrm{pH}$, GBST can then selectively adsorb $\mathrm{Cr}$ (III) or $\mathrm{Cr}$ (VI), this makes PBST-RSP a very promising solid phase extractant in the chromium speciation analysis.

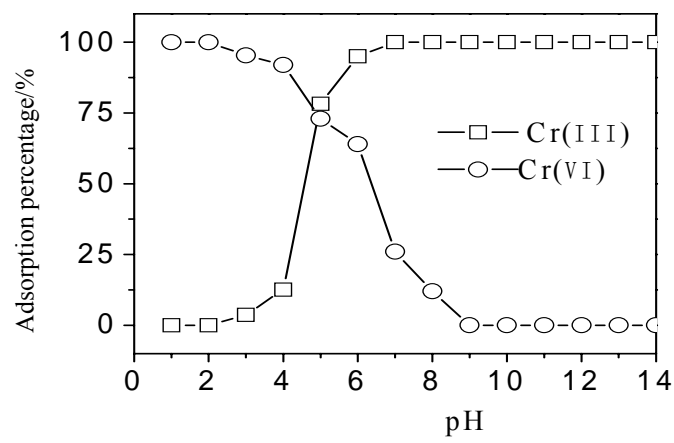

Figure 1. Effect of $\mathrm{pH}$ on the adsorption

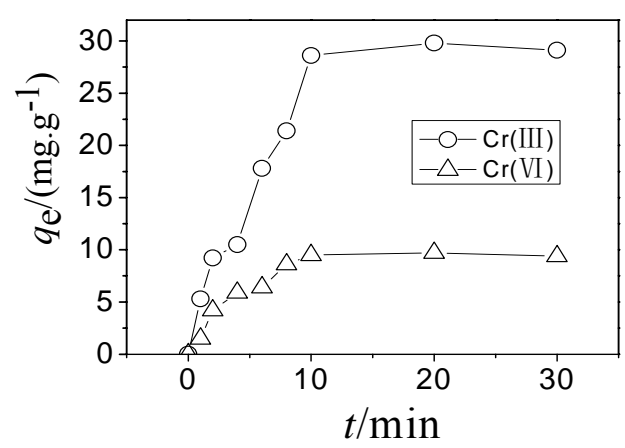

Figure 2. Effect of shaking time on adsorption

\section{Effect of contact time}

At room temperature, the adsorption capacities for $\mathrm{Cr}$ (III) and $\mathrm{Cr}$ (VI) were determined with different shaking times (Fig.2). The results indicate that the adsorption capacity increased with an increase in shaking time and reached equilibrium more than $10 \mathrm{~min}$. Therefore, the shaking time was 20 min in this study.

\section{E Adsorption capacity}

According to Fig.2, at room temperature, the static adsorption capacities of SGCTO to $\mathrm{Cr}$ (III) and $\mathrm{Cr}$ (VI) were $29.8 \mathrm{mg} / \mathrm{g}$ and $9.7 \mathrm{mg} / \mathrm{g}$, respectively.

\section{F Elution conditions}

Fig. 1 shows that the adsorption of $\mathrm{Cr}$ (III) at $\mathrm{pH} \leq 2$ and $\mathrm{Cr}$ (VI) at $\mathrm{pH} \geq 9$, could be negligible. So, after the $\mathrm{Cr}$ (III) and $\mathrm{Cr}$ (VI) were adsorbed under the optimized adsorption conditions. Elution of $\mathrm{Cr}$ (III) and $\mathrm{Cr}$ (VI) from PBST-RSP surface, by $\mathrm{HCl}$ and $\mathrm{NaOH}$, respectively, at different concentrations and volumes was investigated. Recovery was quantitative $(>95 \%)$ with $5 \mathrm{~mL} 1 \mathrm{~mol} / \mathrm{L} \mathrm{NaOH}$ and $5 \mathrm{~mL} 1 \mathrm{~mol} / \mathrm{L} \mathrm{HCl}$ for $\mathrm{Cr}(\mathrm{VI})$ and $\mathrm{Cr}(\mathrm{III})$, respectively.

After elution, the PBST-RSP was dried and reused 20 times. Its adsorption performance did not decrease, indicating that this adsorption agent was very stable.

\section{G Effect of coexisting ions}

The influences of possible matrix ions in the environmental samples and some transition metals were also examined. So various interference ions, such as $\mathrm{Na}^{+}$, $\mathrm{K}^{+}, \mathrm{Mg}^{2+}, \mathrm{Ca}^{2+}, \mathrm{Mn}(\mathrm{VII}), \mathrm{Pb}^{2+}, \mathrm{Cd}^{2+}, \mathrm{Zn}^{2+}, \mathrm{Cu}^{2+}, \mathrm{Al}^{3+}$, $\mathrm{Mn}(\mathrm{II}), \mathrm{Co}^{2+}$ and $\mathrm{Fe}^{3+}$, were added into $50 \mathrm{~mL}$ volumetric flask containing $0.25 \mu \mathrm{g}$ of $\mathrm{Cr}(\mathrm{VI})$ and $\mathrm{Cr}(\mathrm{III})$. The recovery of heavy metal ions were determined according to experimental method with the error controlled within $\pm 5 \%$. The results showed that in the presence of $1000 \mathrm{mg} \cdot \mathrm{L}-1 \mathrm{Na}^{+}$, $\mathrm{K}^{+}, 500 \mathrm{mg} / \mathrm{L} \mathrm{Mg}^{2+}, \mathrm{Ca}^{2+}, \mathrm{Mn}(\mathrm{VII}), 200 \mathrm{mg} / \mathrm{L} \mathrm{Mn}(\mathrm{II})$, $\mathrm{Zn}^{2+}, 50 \mathrm{mg} \cdot \mathrm{L}-1 \mathrm{Al}^{3+}, \mathrm{Pb}^{2+}, \mathrm{Cd}^{2+}, \mathrm{Cu}^{2+}, \mathrm{Co}^{2+}$ and $\mathrm{Fe}^{3+}$. The recoveries of the analytes were still above $95 \%$. It can be seen that the presence of major cations had no obvious influence on the recovery under the selected conditions. 


\section{$H$ Application to the real samples}

The proposed method was applied to the separation, preconcentration and determination of $\mathrm{Cr}$ (III) and $\mathrm{Cr}$ (VI) in environmental water samples. The water samples were filtered through a $0.22 \mu \mathrm{m}$ membrane filter and analyzed immediately. The analytical results and the associated recovery are given in Table 2 . The recoveries were $93.1 \%$ $97.5 \%$ for $\mathrm{Cr}$ (III) and $94.5 \%$ - $102.3 \%$ for $\mathrm{Cr}(\mathrm{VI})$, which are excellent for trace analysis.

TABLE 2. RESULTS FOR THE DETERMINATION OF CR(III) AND CR(VI) IN THE WATER SAMPLES

\begin{tabular}{ccccccccc}
\hline \multirow{2}{*}{ Samples } & \multicolumn{2}{c}{ Found $(\mathrm{mg} / \mathrm{L})$} & \multicolumn{2}{c}{ Added $(\mathrm{mg} / \mathrm{L})$} & \multicolumn{2}{c}{ Recovered $(\mathrm{mg} / \mathrm{L})$} & \multicolumn{2}{c}{ Recovery percentage (\%) } \\
\cline { 2 - 8 } & $\mathrm{Cr}(\mathrm{III})$ & $\mathrm{Cr}(\mathrm{VI})$ & $\mathrm{Cr}(\mathrm{III})$ & $\mathrm{Cr}(\mathrm{VI})$ & $\mathrm{Cr}(\mathrm{III})$ & $\mathrm{Cr}(\mathrm{VI})$ & $\mathrm{Cr}(\mathrm{III})$ & $\mathrm{Cr}(\mathrm{VI})$ \\
\hline Tap water & 0.0082 & 0 & 0.1 & 0.1 & 0.1071 & 0.0937 & 98.9 & 93.7 \\
River water & 0.0124 & 0.0136 & 0.1 & 0.1 & 0.1161 & 0.1128 & 103.7 & 99.2 \\
Lake water & 0.1150 & 0.0171 & 0.1 & 0.1 & 0.2105 & 0.1146 & 95.5 & 97.5 \\
\hline
\end{tabular}

\section{IIICONCLUSIONS}

The reversed-phase suspension polymerization and sol-gel method (PBST-RSP) was used for separation and preconcentration of $\mathrm{Cr}(\mathrm{III})$ and $\mathrm{Cr}(\mathrm{VI})$. Two forms of chromium showed different exchange capacities at different $\mathrm{pH}$ values, viz. Cr (III) selectively retained at $\mathrm{pH} 7-14$, whereas $\mathrm{Cr}$ (VI) retained at $\mathrm{pH}$ 1-2. Hence complete separation of the two forms of chromium was possible. Retained species were eluted with $5 \mathrm{~mL}$ of $1 \mathrm{~mol} / \mathrm{L} \mathrm{HCl}$ and $1 \mathrm{~mol} / \mathrm{L} \mathrm{NaOH}$. The method has been applied to the preconcentration and separation for flame atomic absorption spectrometric determinations of $\mathrm{Cr}(\mathrm{III})$ and $\mathrm{Cr}(\mathrm{VI})$ in environmental water samples with satisfied results.

\section{REFERENCES}

[1] P. Bermejo-Barrera, M.C. Barciela-Alonso, B. Perez-Fernandez, A.Bermejo-Barrera, Spectrochim. Acta Vol.58B, 167-172(2003).
[2] J. Kotas, Z. Stasicka, Environ. Pollut. Vol.107, 263-269(2000).

[3] P. Pazos-Capeans, M.C. Barciela-Alonso, A. Bermejo-Barrera, P. Bermejo-Barrera, Talanta, Vol. 65, 678-685(2005).

[4] M. de la Guardia, A. Morales-Rubiol, Sample preparation for chromium speciation, in: D. Barcel'o (Ed.), In Comprehensive Analytical Chemistry XLI (Elsevier Science, Amsterdam, Netherlands, pp. 1115-1171,2003).

[5] Edmar Martendal, Heloisa Franc a Maltez, Eduardo Carasek. Journal of Hazardous Materials Vol.161, 450-456(2009).

[6] Standards for drinking water quality, GB 5749-2006.

[7] G.F. Nordberg, B.A. Fowler, M. Nordberg, L. Friberg, Handbook on the Toxicology of Metals, (Academic Press, Burlington, 2007).

[8] Ibrahim Narin, Yavuz Surme, Mustafa Soylak, Mehmet Dogan. Journal of Hazardous Materials B Vol.136, 579-584(2006).

[9] State Environmental Protection Administration of China. Analysis method of water and waste water, fourth ed., (China Environmental Science Press, Inc. Beijing, 286-418, 2002).

[10] Min Wang, Dong Zhang, De chang Han, Wen-jie Zhang, Journal of the Chinese Ceramic Society, 38, 305 (2010). 